\title{
Study on "2 + 1 + 1" Applied Talents Training Mode in Computer Science and Technology Major
}

\author{
Zijiang Zhu' ${ }^{1, a}{ }^{*}$, Weihuang Dai ${ }^{2, b}, Y_{i ~ H u}^{3, c}$, Dong Liu, ${ }^{4, d}$ and Junshan $\mathrm{Li}^{5, \mathrm{e}}$ \\ $1,2,3,4,5$ South China Business College of Guangdong University of Foreign Studies, Guangzhou, \\ 510545, China \\ azzjdwh2002@163.com, b975690566@qq.com, c444187113@qq.com, d78972493@qq.com, \\ elijunshan403@163.com
}

Keywords: Computer science and technology; Applied talents; Training mode; Practice teaching

\begin{abstract}
The problems such as unclear orientation of curriculum system, weak pertinence of practical teaching, and the difficulty of internship outside the university are analyzed in this paper, and " $2+1+1$ " training model of applied talents is proposed. The training mode designs talent training program revolving around IT applied talent training target, effectively improving the students' practical ability and employment competitiveness through the integration of course content, teaching method reform, joint practice teaching with school-enterprise double tutor and other methods, thus it has a certain exemplary role for the peer computer majors reform.
\end{abstract}

\section{Introduction}

China's higher education has entered the mass education phase from the early elite education and has diversified its levels and types of running schools [1]. Nowadays, with the rapid development of IT technology, it is an unshakable responsibility to cultivate IT application talents in line with the actual needs of the society and enterprises. This requires the educators to reform the personnel training mode in elite education and to explore the new mode and new method to meet the requirements of popularization education stage. At present, there are many criticisms on the training mode of computer science and technology professionals, and the content of teaching lags behind the development of technology. The reform of teaching mode is bound to the integrity of the curriculum system, resulting in the implementation of practical teaching stops at the campus, and so on [2]. Southern China Business School, Guangdong University of Foreign Studies is an applied undergraduate college. With the goal of cultivating applied talents in line with the economic development of Guangdong Province and the Pearl River Delta, the Southern China Business School of Guangdong University of Foreign Studies has conducted in-depth study of new models and methods for cultivating applied talents in computer major for many years, and achieved good results.

\section{Current Situation of Computer Science and Technology Applied Talents Training}

The main problem faced by computer science and technology reform is to cultivate what type of personnel, what kind of professionals, basic skills and professional core competitiveness the trained personnel should have. Around this issue, domestic applied undergraduate colleges have done a lot of research and practice on computer application talents training mode. In the process of construction and development in the recent 20 years, with the change of social needs for IT professionals, the mode of personnel training has also been correspondingly changed. From the " $7+$ 1 " model of initial research-type personnel training (the first to seventh semesters for theory learning at school, and the eighth semester for graduation project and graduation practice), transited to the " $3+1$ " mode of application-oriented personnel training (the first 3 years for theory learning at school, the last 1 year for business internship and completing graduation design) [3]. Through the research and practice of " $3+1$ " personnel training mode, a more scientific and humanized and improved " $3+1$ " training mode has also been explored. For example, the "Yuanpei Plan" mode adopted by Peking University, and "KAQ" mode adopted by Zhejiang University [4]. 
The research on " $3+1$ " talent training mode in colleges and universities provides an important theoretical understanding and practical case for the training of IT applied talents. In theory, computer science and technology major is to cultivate the talents needed by socio-economic development; in practice, a great deal of exploration with reference significance is made from different levels and different types of application talents [5]. However, from the practice of " $3+1$ " model, there are three main problems in the following aspects: 1) The positioning of curriculum system is not clear. In the three years of school theoretical study, the number of theoretical courses and the number of academic hours are too much, and the principle of "theoretically enough" cannot be applied according to the training of applied talents. Therefore, the curriculum system cannot be designed according to the demand of talent market, making most students difficult to be engaged in professional internships after entering into the enterprises after 3 years. They do not have the professional core competitiveness. 2) practical teaching is not targeted. During the three years of studying in school, most of the institutions only pay attention to the practical training of the course, adopting the practice teaching mode of one practice for one lesson and curriculum design. However, the cohesion of the curriculum is low and the coupling between the courses is high, which leads to the consistency of practice teaching system is poor, and the contents are repeated serious. 3) difficult to practice outside the campus. The construction of off-campus internship base requires that the schools and enterprises have higher consensus, which requires schools and enterprises to devote more manpower, material resources and financial resources so as to ensure sufficient internship positions so that graduation internship is no longer mere formality. This is the main problem that exists in practical teaching in colleges and universities.

\section{“2+1+1" Talent Training Mode}

In response to the above questions, Southern China Business School of Guangdong University of Foreign Studies has put forward a " $2+1+1$ " applied talents training model, which is improved based on the practice of " $3+1$ " mode. The first three years theoretical learning at school are divided " $2+1$ ", that is, the first two years for general education, basic education, and learning foreign languages, mathematics, computer science basic courses; the last year for major (professional direction) education, and learning professional courses, professional direction courses that mainly include software designers, database systems engineers and multimedia designers in three directions; 1 year for comprehensive practical education, including business training, graduation practice and graduation design. The overall framework of its personnel training mode is shown in Figure 1. Practice of teaching is throughout these 4 years, including enterprise probation, business engineer lectures and curriculum design for freshman and sophomore; integrated practice for the junior, when small and medium sized project development is the main task; school-enterprise dual tutor model is mainly used for teaching; in the fourth year, practical training and graduation project are the main task, where business training is respond by the business tutors, and graduation design is carried out with the forms of proposed title and classified guidance [6].

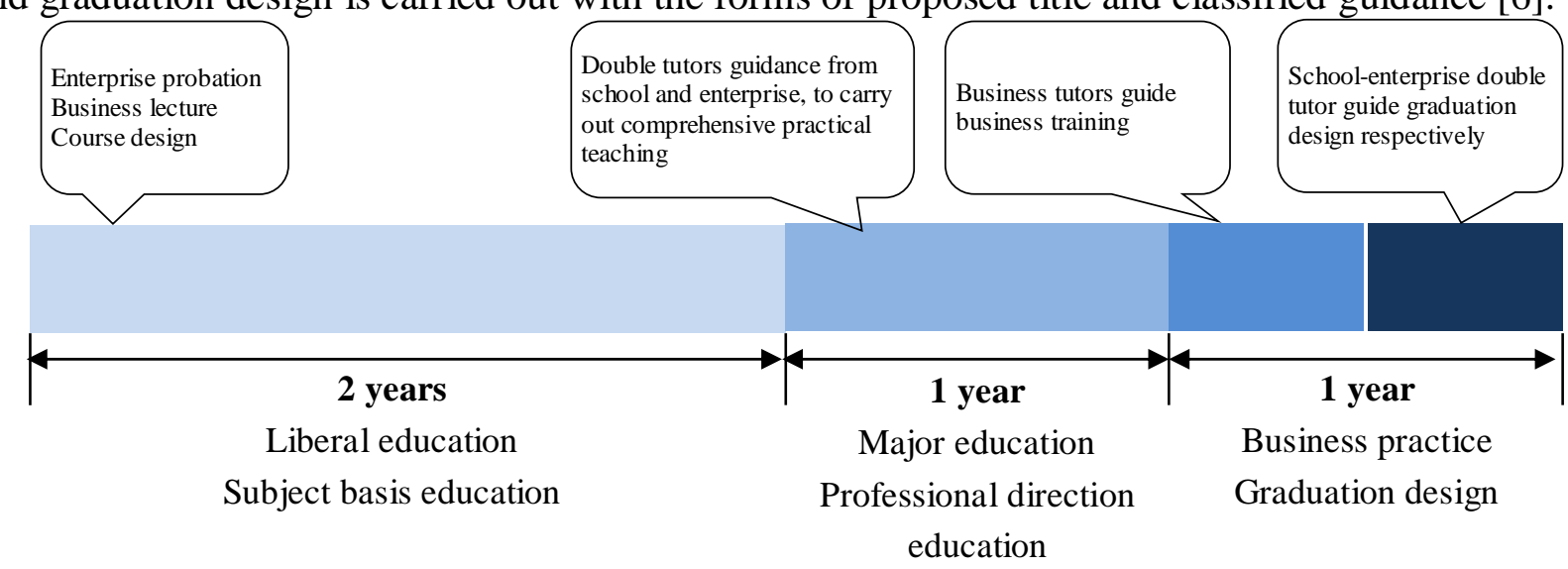

Figure 1. General framework of " $2+1+1$ ” applied talents training mode 
The implementation and teaching of this model is more targeted, and students' learning objectives are clearer. According to the learning situation of freshman and sophomore, students are clearer about their future direction of development, and will be no longer confused in the choice of professional direction. Through professional orientation courses and comprehensive practice courses, at junior, they can link the theory and practice of each course organically, making the course no longer isolated. At the same time, it also reduces the repetition of course contents and greatly improves teaching efficiency and teaching quality. Through the first two years of study, nearly $30 \%$ of the students can pass the Computer Technology and Software Professional Qualification (Level) Examination during their third year of junior college and obtain the certificate of qualification of software engineer, database system engineer and multimedia designer intermediate engineer. During the fourth year, they can enter into the enterprises for internship or be directly employed by the enterprises successfully.

\section{Talent Training Program Design}

The design of talent training programs for undergraduate education in computer science and technology should emphasize practice teaching and strengthen students' mastery of basic theoretical knowledge through practice teaching. Both should not be isolated and should be complemented by each other to form an organic whole [7]. At the same time, in the design of personnel training programs, the demand for IT talents should be fully investigated, at present, IT professionals are generally divided into three categories: 1) Engaged in a new generation of computer hardware and software core technology research personnel; 2) Engaged in IT technology projects development; 3) Engaged in IT product sales, operation and maintenance and technical support. The first type of talents belongs to the high-end research talent, and the demand is small, but also a certain amount of time and accumulated work experience is required. Thus, it's impractical to position their training in applied undergraduate colleges; the second and third categories of talents are applied talents, in particular, there is a greater social need for the second category of personnel.

According to the requirements of application-oriented personnel training and IT talents, the training objectives of computer science and technology professionals are as follows: to cultivate the high-quality internationalization, applied, innovative senior specialized personnel with good knowledge of information science, mastery of the professional basic theory, systematical basic knowledge and basic skills, the spirit of innovation and teamwork, and can be engaged in computer science and technology-related research, design, and system maintenance and other work in the field of computer systems and computer applications, enterprises, institutions, government and departments with all-round development [8]. The professional orientation takes the needs of IT professionals in the Pearl River Delta Region of Guangdong Province as the goal, and three professional directions for software designers, database system engineers and multimedia designers are set to train students to be engaged in the work of software maintenance and development, database maintenance and development, and multimedia design [9].

Talents training program takes talents training objectives as the main line, building " $2+1+1$ " application-based personnel training mode, improving the integrating degree between personnel training objectives and talent market demand. Through business personnel demand research and new technology development trends, " $2+1+1$ " personnel training program is developed. The curriculum system is shown in Table 1 . 
Table $1 \quad 2+1+1 ”$ Applied Talents Cultivation Course System

\begin{tabular}{|c|c|c|c|c|}
\hline Mode & \multirow{2}{*}{\multicolumn{2}{|c|}{$\begin{array}{c}\text { Curriculum module } \\
\begin{array}{c}\text { Liberal education } \\
\text { curriculum }\end{array} \\
\end{array}$}} & Curriculum system & $\begin{array}{l}\text { Practical } \\
\text { teaching }\end{array}$ \\
\hline \multirow[b]{2}{*}{$\begin{array}{l}2 \text { years } \\
\text { Freshman } \\
\text { Sophomore }\end{array}$} & & & $\begin{array}{l}\text { Political science class, math class, } \\
\text { sports, English, general elective }\end{array}$ & Business visit \\
\hline & \multicolumn{2}{|c|}{ subject basis curriculum } & $\begin{array}{l}\text { Electronic Technology Foundation, } \\
\text { Digital Circuit and Logic Design, } \\
\text { Discrete Mathematics, Program } \\
\text { Design, Data Structures and } \\
\text { Algorithms, Operating Systems, } \\
\text { Principles of Computer } \\
\text { Organization, Computer Networks, } \\
\begin{array}{l}\text { Database Principles and } \\
\text { Applications }\end{array}\end{array}$ & $\begin{array}{l}\text { business tutor } \\
\text { technology } \\
\text { seminar, electronic } \\
\text { course design, } \\
\text { operating system } \\
\text { course design, } \\
\text { program design } \\
\text { course design }\end{array}$ \\
\hline \multirow{4}{*}{$\begin{array}{l}1 \text { year } \\
\text { Junior }\end{array}$} & \multirow{4}{*}{$\begin{array}{l}\text { Professional } \\
\text { Courses } \\
\text { professional } \\
\text { direction } \\
\text { (elective) }\end{array}$} & $\begin{array}{c}\text { Major } \\
\text { foundation }\end{array}$ & $\begin{array}{l}\text { Software } \\
\text { object-oriented progineering, } \\
\text { multimedia technology, network } \\
\text { operating system }\end{array}$ & $\begin{array}{l}\text { Integrated } \\
\text { programming } \\
\text { practice }\end{array}$ \\
\hline & & $\begin{array}{l}\text { Software } \\
\text { designer } \\
\text { direction }\end{array}$ & $\begin{array}{l}\text { JAVA programming, WEB database } \\
\text { technology, mobile application } \\
\text { development, software testing } \\
\text { technology, HTML5 technology }\end{array}$ & $\begin{array}{l}\text { Software design } \\
\text { and development } \\
\text { integrated practice }\end{array}$ \\
\hline & & $\begin{array}{l}\text { Database } \\
\text { system } \\
\text { engineer } \\
\text { direction }\end{array}$ & $\begin{array}{l}\text { Advanced database technology, } \\
\text { database application system design } \\
\text { and implementation, database } \\
\text { operation and management, cloud } \\
\text { computing and data disaster } \\
\text { recovery, big data technology and } \\
\text { applications }\end{array}$ & $\begin{array}{l}\text { Integrated practice } \\
\text { of database design } \\
\text { and development }\end{array}$ \\
\hline & & $\begin{array}{l}\text { Multimedia } \\
\text { designer } \\
\text { direction }\end{array}$ & $\begin{array}{l}\text { Multimedia data processing, 3D } \\
\text { modeling and animation design, } \\
\text { video production and editing, UI } \\
\text { design, Unity } 3 \mathrm{~d} \text { animation design }\end{array}$ & $\begin{array}{l}\text { Multimedia design } \\
\text { and production of } \\
\text { integrated practice }\end{array}$ \\
\hline \multirow{2}{*}{$\begin{array}{l}1 \text { year } \\
\text { Senior }\end{array}$} & \multicolumn{2}{|c|}{ Enterprise practice } & $\begin{array}{l}\text { Internship or to participate in } \\
\text { business training according to } \\
\text { professional orientation }\end{array}$ & $\begin{array}{l}\text { Business tutor } \\
\text { guides integrated } \\
\text { practice }\end{array}$ \\
\hline & \multicolumn{2}{|c|}{ Graduation design } & $\begin{array}{l}\text { Optional topics, dual tutors propose } \\
\text { the topics }\end{array}$ & $\begin{array}{l}\text { School-enterprise } \\
\text { dual tutors guide } \\
\text { graduation design }\end{array}$ \\
\hline
\end{tabular}

In Table 1, basic course is the professional compulsory courses, and the professional direction courses are selected by the students according to their own interests and the direction of future development. When the students enter junior, a professional orientation course must be selected in order to ensure the integrity and continuity of the course system, and the students cannot withdraw or re-election.

\section{Implementation of Teaching}

In order to ensure the training quality of applied talents in computer science and technology, effective measures should be taken to improve the teaching effectiveness in teaching arrangements, teaching reform and construction of practical environment [10].

Teaching Arrangement. At present, there are only 16 weeks for the first semester when freshmen enter the university and attend the military training in the domestic universities. The other 
semesters generally have 18 teaching weeks. Since the " $2+1+1$ " mode has been implemented, the following teaching arrangements have been adopted. See Table 2. From the second to the sixth semester, "16+2" model is used for teaching. Two weeks in each semester are used for practice teaching. The time can be arranged in the middle or the end of the semester according to the course schedule. In order to protect the practice teaching week, 1 credit of professional practice is set in each semester. Students participate in the practice from the lower grades subject to credits, to the higher grades participating in the practice voluntarily. The practice teaching week has not only systematically sorted out the theoretical knowledge of the course but also improved the practical ability of the students, breaking the traditional teaching mode for practice of each lesson, forgetting after the exams and successfully, stimulating students' learning interest.

Table 2 teaching arrangements

\begin{tabular}{|c|c|c|l|}
\hline Semester & $\begin{array}{c}\text { Theory teaching } \\
\text { week }\end{array}$ & $\begin{array}{c}\text { Practical } \\
\text { teaching week }\end{array}$ & \multicolumn{1}{|c|}{ Remark } \\
\hline 1 & 16 weeks & - & $\begin{array}{l}\text { enrollment military training; enterprise } \\
\text { probation, technical seminars }\end{array}$ \\
\hline $2-6$ & 16 weeks & 2 weeks & $\begin{array}{l}\text { 2 weeks are used to finish the practical } \\
\text { teaching }\end{array}$ \\
\hline 7,8 & - & 18 weeks & $\begin{array}{l}\text { Not less than 16 weeks of internships or } \\
\text { business training, completing the graduation } \\
\text { project }\end{array}$ \\
\hline
\end{tabular}

\section{Teaching Reform.}

Teaching mode and teaching method reform. We should reform the past teacher-centered teaching method and turn it into a student-centered teaching around the ability of students' problems analysis and solving. Teachers make full use of Internet technology to make online courses and micro-video courses on the Black Board teaching platform, and teach the course contents by using advanced teaching methods such as flipped classroom, case teaching and project-driven teaching. Through the QQ group, WeChat group, etc. the dynamics learning of student can be learned, and teaching progress can be adjusted timely according to the students' situation of learning.

Integrate teaching content. Considering the low degree of cohesion of disciplinary basic courses, the course contents are integrated according to the content of curriculum design practice, and the content and syllabus are studied and sorted out, and the relevant repetitive contents are removed, the theoretical teaching time is reduced, thus the practice teaching is provided with time guarantee. For example, the discipline basic course teaching is arranged with 3 comprehensive curriculum design: electronic course design includes electronic technology foundation, digital circuit and logic design and discrete math course content; operating system course design includes operating system, computer composition principle and computer network course content; program design course design includes program design and database course content. Through the course design, students have a comprehensive understanding and cognitive for computer science.

School-enterprise dual tutors carry out joint practice teaching. In the comprehensive practical teaching in the practical teaching week of the 5th and 6th semester, it is jointly guided by the double tutors of school and enterprises. The enterprise R\&D project case is taken as the practical content, and the business tutor is responsible for project decomposition and technical explanation, the school tutor is responsible for supervising the completion of the student team project progress, troubleshooting and project reporting. The project case comes from the recently developed product or part of the product. Students can not only truly experience the process of enterprise work and project development, but also learn new technologies from them, pointing the way for the follow-up internship and employment. Through the exchange and communication with business tutors, teachers can also understand the development of new technologies and practical applications, professional skills have been further improved.

Practical Environment Construction. Firstly, the school laboratory construction. Laboratory is an important place for application-oriented personnel training. It needs enough manpower, material 
and financial resources to regularly update and maintain, and comprehensively covers the hybrid practice teaching in the curriculum system. The laboratory management is improved. In addition to the normal teaching hours, open laboratories to students to provide necessary conditions for students to learn after class. The establishment of student science and technology activities group makes students carry out a variety of extra-curricular practice with self-management model. At the same time, an innovation laboratory for undergraduates should be set up to provide an environment for scientific and technological activities teams. Secondly, off-campus internship base construction. Strengthen cooperation between schools and enterprises, jointly declare science and technology projects and demonstration practical teaching bases, and organize teachers and students to participate in the development of small-scale enterprise software systems; and employ practical engineers as part-time teachers to conduct practical teaching, business training and graduation design guidance.

\section{Conclusion}

After several years of practice, the professional characteristics of the " $2+1+1$ " application-oriented personnel training mode of Southern China Business School of Guangdong University of Foreign Studies are gradually highlighted. The number of corporate internship is increased year by year, the satisfaction of enterprises for the graduates is gradually promoted, and a virtuous circle is formed. The envisaged reform in the next step is to further optimize the program of personnel training, strengthen the cooperation between schools and enterprises, enhance the ability of students to start their undertakings and start a business, and comprehensively improve the ability of schools to serve the regional economy and social development as well as the collaborative innovation and development among enterprises [11].

\section{Acknowledgements}

This paper is supported by the Model Demonstration of computer science and technology applied talents training, South China Business College of Guangdong University of Foreign Studies-Guangzhou Xinbao Software Technology Co., Ltd. Out-of-school Practice Teaching Base for Undergraduates in Guangdong Province (Teaching Quality and Teaching Reform Project of Guangdong Province in 2015 for the undergraduate education (Guangdong Education Letter 2015 [133])).

\section{References}

[1] Y.J. Wang, N. Ma and X.L. Niu: Computer Education, Vol. 1 (2015) No.23, p.61-65.

[2] H. Gu: Vocational and Technical Education, Vol.1 (2015) No.20, p.29-31.

[3] J. Li and Y.Y. Qiu: Computer Engineering and Science, Vol. 33 (2011) No.A1, p.13-15.

[4] H.R. Shen, X.Y. Peng and Z.J. Wang: Journal of Kunming University, Vol. 39 (2017) No.3, p.124-129.

[5] Y. Yuan: China Adult Education, Vol. 1 (2014) No.7, p.30-33.

[6] M.Y. Deng: Vocational and Technical Education, Vol. 1 (2013) No.20, p.57-60.

[7] R.B. Lu, Z.C. Li and W.Y. Duan: College Journal of Jishou University(Natural Science Edition), Vol. 37 (2016) No.3, p.94-96.

[8] Department of Higher Education, Ministry of Education, People's Republic of China: Catalog and Professional Introduction to Regular Colleges and Universities (Higher Education Press,China 2012), p.193-195.

[9] C.D. Deng, C. Sun and J.C. Li: China Higher Education Research, Vol. 1 (2013) No.4, p.86-90.

[10] C.R. Huang and J.D. Zhang: Computer Education, Vol. 1 (2017) No.3, p.14-16.

[11]E.T. Luo, L.S. Huang and Y.Y. Tang: Laboratory Research and Exploration, Vol. 1 (2017) No.7, p.253-256. 